\title{
First report of sheath rot caused by Fusarium proliferatum on Pisang Awak Banana (Musa ABB) in China
}

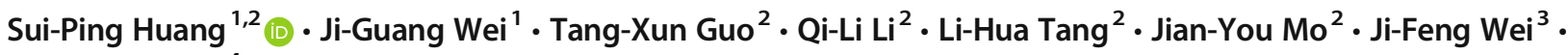 \\ Xiao-Bing Yang ${ }^{4}$
}

Received: 19 November 2018 / Accepted: 20 May 2019/Published online: 20 June 2019

(C) The Author(s) 2019

Keywords Pisang Awak banana $\cdot$ Sheath rot $\cdot$ Fusarium proliferatum

Pisang Awak banana (Musa ABB) is the second largest banana variety cultivated in China. A severe sheath disease of Pisang Awak banana with disease incidence of over $90 \%$ was observed in a plantation in Du'an County, Guangxi, China in 2017. Black punctiform lesions first appeared on the sheaths connecting petioles to stems. As lesions expanded, the leaves wilted and broke off near the base, causing the sheaths to die and rot away. Symptomatic plants had smaller stems and reduced yields. A fungus was consistently isolated from the surfacesterilized sheath samples. The isolate XJSF had abundant aerial white mycelia on potato dextrose agar (PDA). Microconidia on PDA were aseptate, club shaped, 4.25 to $8.57 \times 1.7$ to $3.21 \mu \mathrm{m}$ (average $5.90 \times 2.34 \mu \mathrm{m}$ ). Macroconidia on carnation leaf agar were slender, almost straight, 3-4 septate, 32.9 to $57.6 \times 2.51$ to $4.55 \mu \mathrm{m}$ (average $44.53 \times 3.57 \mu \mathrm{m})$. The internal transcribed spacer (ITS) of the ribosomal DNA sequences

Electronic supplementary material The online version of this article (https://doi.org/10.1007/s42161-019-00329-z) contains supplementary material, which is available to authorized users.

Jian-You Mo

mojianyou@gxaas.net

Sui-Ping Huang

361566787@qq.com

1 College of Agriculture, Guangxi University, Nanning 530004, Guangxi, China

2 Plant Protection Research Institute, Guangxi Academy of Agricultural Sciences, Nanning 530007, Guangxi, China

3 Department of Scientific Research Management, Guangxi College of Education, Nanning 530023, Guangxi, China

4 Iowa State University, Ames, IA 50011, USA
(GenBank accession number MF083155) and the translation elongation factor 1 -alpha $(\mathrm{EF}-1 \alpha)$ gene sequences (MF083156) (O'Donnell et al. 1998) were deposited in GenBank. BlastN searches showed $100 \%$ and $99 \%$ identity to F. proliferatum strains U34558 and AF160280.1, respectively. The fungus was therefore identified as Fusarium proliferatum, based on morphological (Leslie and Summerell 2006) and ITS and EF-1 $\alpha$ sequences analysis. Pathogenicity tests were performed on the sheaths of healthy Pisang Awak banana plantlets with a conidial suspension $\left(1 \times 10^{6}\right.$ conidia/ml $)$ of the XJSF isolate according to the method of Huang et al. (2017). After three months, the whole sheaths of inoculated plants were rotted while only slight scars formed on the control plants. Fungi re-isolated from the lesions were identified as F. proliferatum based on morphology. To our knowledge, this is the first report of sheath rot on banana (Musa ABB) caused by $F$. proliferatum world-wide.

Acknowledgements This work was financed by the National Key R\&D Program of China (Grant No. 2016YFC1202100), Science and Technology Major Project of Guangxi (Grant No. AA18118028) and Planned Project of Scientific Research and Technology Development in Qingxiu District, Nanning City (Award Number 2017040).

\section{Compliance with ethical standards}

Conflict of interest The authors declare that they have no conflict of interest.

Research involving human participants and/or animals The authors declare that no human participants and animals were involved in this study.

Informed consent Informed consent was obtained from all individual participants included in the study. 
Open Access This article is distributed under the terms of the Creative Commons Attribution 4.0 International License (http:// creativecommons.org/licenses/by/4.0/), which permits unrestricted use, distribution, and reproduction in any medium, provided you give appropriate credit to the original author(s) and the source, provide a link to the Creative Commons license, and indicate if changes were made.

\section{References}

Huang SP, Li ZL, Wei JG et al (2017) First report of stem canker caused by Fusarium solani on Tectona grandis in China. Plant Dis 101(12): $2148-2148$
Leslie JF, Summerell BA (2006) The Fusarium laboratory manual. Blackwell Publishing, Oxford

O’Donnell K, Kistler HC, Cigelnik E et al (1998) Multiple evolutionary origins of the fungus causing Panama disease of banana: concordant evidence from nuclear and mitochondrial gene genealogies. Proc Natl Acad Sci 95(5): 2044-2049

Publisher's note Springer Nature remains neutral with regard to jurisdictional claims in published maps and institutional affiliations. 